\title{
Neuronal Differentiation of Precursors in the Neocortical Ventricular Zone Is Triggered by BMP
}

\author{
Weiwei Li, Catherine A. Cogswell, and Joseph J. LoTurco \\ Department of Physiology and Neurobiology, University of Connecticut, Storrs, Connecticut 06269-4156
}

\begin{abstract}
Neocortical neurons begin to differentiate soon after they are generated by mitoses at the surface of the ventricular zone (VZ). We provide evidence here that bone morphogenetic protein (BMP) triggers neuronal differentiation of neocortical precursors within the VZ. In cultures of dissociated neocortical neuroepithelial cells, BMPs increase the number of MAP-2- and TUJ1positive cells within $24 \mathrm{hr}$ of treatment. In explant cultures, BMP-4 treatment leads to an increase in the number of TUJ1positive cells within the ventricular zone. Furthermore, truncated, dominant-negative, BMP type I receptor, introduced into
\end{abstract}

The majority of neurons that populate the mature cerebral cortex are generated by cellular divisions that occur at the surface of the lateral ventricles within the fetal telencephalon (BoulderCommittee, 1970). In mouse, terminal divisions at the ventricular zone (VZ) surface occur between gestational days 13 and 17, with the majority of neocortical neurons generated on the last $2 \mathrm{~d}$ of this period (Takahashi et al., 1995, 1996). After their last cytokinesis at the VZ surface, neuronal precursors migrate through and then out of the ventricular zone into the intermediate zone (Rakic, 1972; McConnell, 1988; Hatten, 1990; Misson et al., 1991). Recent studies on migration of neural precursors from the $\mathrm{VZ}$ indicate that precursors can rapidly migrate away from the VZ surface, either radially or tangentially (O'Rourke et al., 1992, 1995; Takahashi et al., 1992; Fishell et al., 1993; Walsh and Cepko, 1993), and it is thought that this migration precedes or is coincident with neuronal differentiation. In addition, at least some neocortical cells begin to differentiate while still within the VZ. For example, some cells within the VZ express neurotransmitters, neurotransmitter receptors (Parnavelas and Cavanagh, 1988; Chun and Shatz, 1989; Van Eden et al., 1989; Cobas et al., 1991; LoTurco et al., 1991; Del Rio et al., 1992; Schwartz and Meinecke, 1992; Yan et al., 1992), and a neuronal form of $\beta$-tubulin identified by the monoclonal antibody TUJ1 (Lee et al., 1990; Menezes and Luskin, 1994). Signaling molecules that initiate differentiation of neocortical cells must therefore be located at or near the ventricular surface.

Secreted growth factors belonging to the TGF- $\beta$ superfamily have been shown to act early in the differentiation of many cell

\footnotetext{
Received May 19, 1998; revised Aug. 10, 1998; accepted Aug. 12, 1998.

This work was supported by grants from the Ester A. and Joseph Klingenstein Foundation and the Human Frontiers Science Program and by Public Health Service Grant MH56524 to J.J.L. We thank M. Ishibashi for the $\triangle$ mBMPR (mTFR11-45 del 21) plasmid and the Genetics Institute (Cambridge, MA) for human recombinant BMP-2, BMP-4, BMP-6, BMP-7, BMP-12, and BMP-13 protein and BMP-2 and BMP-4 antibody.

Correspondence should be addressed to Dr. Joe LoTurco, Department of Physiology and Neurobiology, University of Connecticut, U-156, Storrs, CT 06269-4156. Copyright (C) 1998 Society for Neuroscience $\quad 0270-6474 / 98 / 188853-10 \$ 05.00 / 0$
}

neocortical precursors by retrovirus-mediated gene transfer, blocks neurite elaboration and migration out of the VZ. Finally, immunocytochemistry indicates that BMP protein is present at the VZ surface. Together, these results indicate that BMP protein is present within the VZ, that BMP is capable of promoting neuronal differentiation, and that signaling through BMP receptors triggers neuronal precursors to differentiate and migrate out of the VZ.

Key words: neurogenesis; neocortex; BMPs; migration; differentiation; development

types (Kingsley, 1994; Mehler and Kessler, 1995; Hogan, 1996; Mehler et al., 1997). For example, in Drosophila, dpp, the homolog of bone morphogenetic protein (BMP)-2 and -4, is necessary for the differentiation and development of many tissues and cells including photoreceptor neurons (Heberlein et al., 1993; Ma et al., 1993). Because BMP-2 and BMP-4 mutant mice die before the majority of neural development has occurred (Winnier et al., 1995), there is little or no direct genetic evidence of a role of BMP-2 and BMP-4 in neuronal differentiation in mammals; however, cell culture experiments clearly indicate that members of the TGF- $\beta$ superfamily promote the differentiation of neural cells. For example, BMP-4 and BMP-7 induce the differentiation of dorsal cell types in the spinal cord (Liem et al., 1995), glial cell line-derived neurotrophic factor and BMPs promote the differentiation of neural crest cells (Maxwell et al., 1996; Shah et al., 1996; Varley and Maxwell, 1996), BMPs promote the differentiation of astroglia from murine embryonic subventricular zone progenitors (Gross et al., 1996), and BMP-7 and BMP-2 stimulate dendritic growth in cultures of sympathetic neurons (Lein et al., 1995).

Because of the importance of BMP signaling in initiating differentiation in many cell types (Kingsley, 1994; Mehler and Kessler, 1995; Hogan, 1996; Mehler et al., 1997), we sought to determine whether members of the BMP superfamily play a role in the differentiation of neocortical neurons. We find that BMPs rapidly promote the differentiation of neocortical precursors in both dissociated cell and explant cultures. In addition, we have used retrovirus-mediated gene transfer to determine that endogenous BMP directly promotes neuronal differentiation of neocortical precursors.

\section{MATERIALS AND METHODS}

$R T-P C R$. Total RNA was prepared from embryonic day 16 (E16) mouse cortex from CD1 mice by the use of the guanidinium thiocyanate-phenolchloroform method. Reverse transcription (RT)-PCR was performed as described by Basler et al. (1993). Degenerate primers designed against conserved regions of TGF- $\beta$ superfamily members were used [5'-TGGAATTCTGG(ACG)A(ACGT)GA(CT)TGGAT(ACT)(AG)T(ACGT)GC3'and 5'-GAGGATCCA(AG)(ACGT)GT(CT)TG(ACGT)AC(AGT)AT(ACGT)GC(AG)TG-3'] in PCR reactions ( $94^{\circ}$ for 5 min, followed by 35 


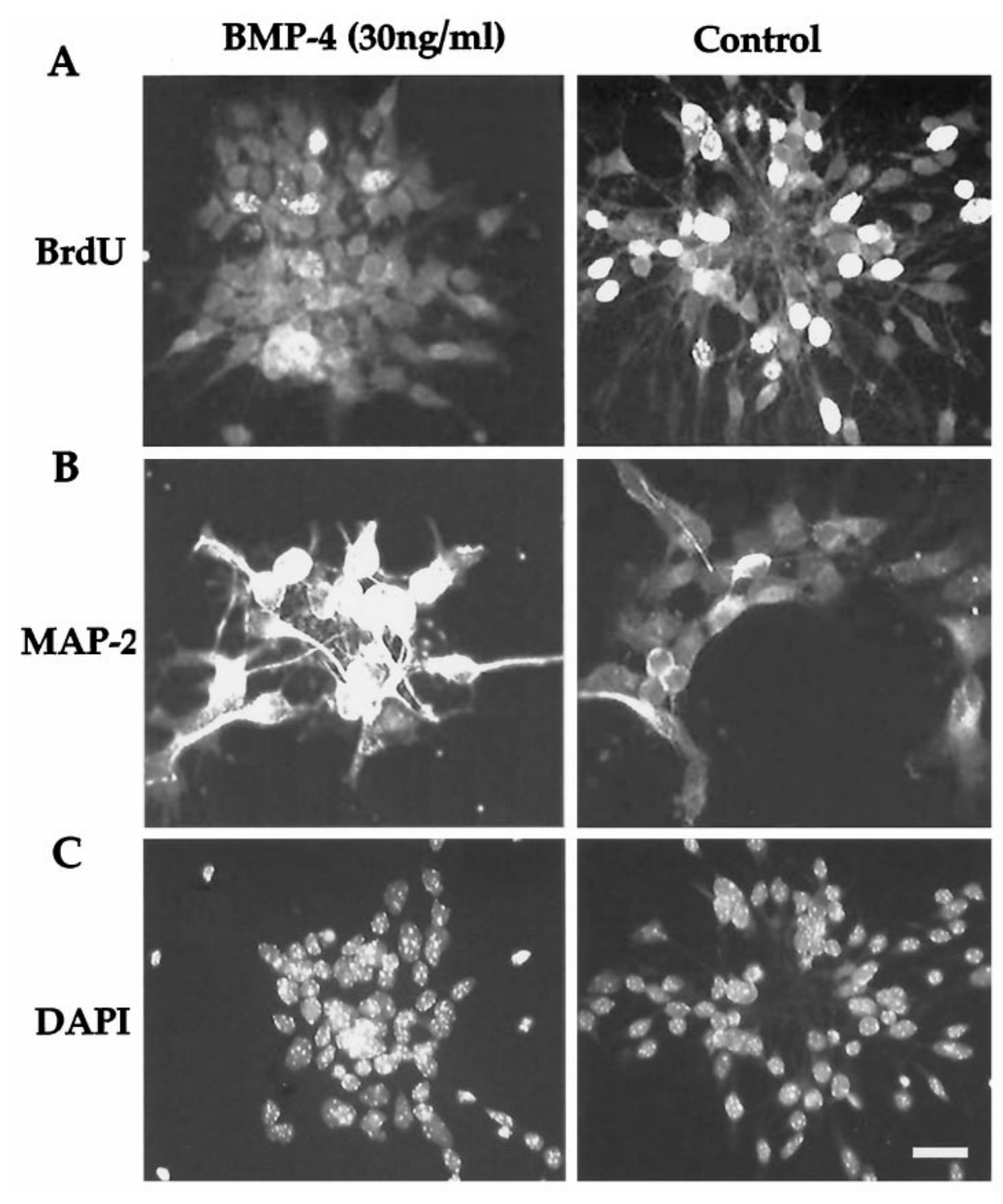

Figure 1. Representative examples of control and BMP-treated cultures. Immunostaining shows that BMPs promote neuronal differentiation and inhibit the number of cells that reenter the cell cycle. $A$, There is a marked reduction in the number of cells incorporating BrdU after BMP-4 treatment relative to that in the control. $B$, More cells are positively stained for the neuronal marker MAP-2 after BMP-4 treatment than in untreated cultures. These positively stained cells have extensive dendritic trees typical of morphologically differentiated cortical neurons. $C$, DAPI nuclei staining shows comparable condensed nuclei and cluster size in control and BMP-4-treated cell cultures. Scale bar, $20 \mu \mathrm{m}$.

rounds at $94^{\circ}$ for $50 \mathrm{sec}, 55^{\circ}$ for $2 \mathrm{~min}$, and $72^{\circ}$ for $1.5 \mathrm{~min}$ ). The $117 \mathrm{bp}$ reaction products were digested with EcoRI and Bam HI, ligated into BS, used to transform bacteria, and sequenced (United States Biochemicals, Cleveland, $\mathrm{OH})$. Sequences were compared with sequences in the database with Blast.

Dissociated cell culture. E12-E13 telencephalons were removed and trimmed to $\sim 2 \mathrm{~mm}$ square explants from dorsal telencephalon. Cells were mechanically dissociated by trituration and plated onto poly-Dlysine- $\left(12.6 \mu \mathrm{g} / \mathrm{cm}^{2}\right)$ and laminin- $\left(1.2 \mu \mathrm{g} / \mathrm{cm}^{2}\right)$ coated $12 \mathrm{~mm}$ coverslips $\left(\sim 2 \times 10^{5}\right.$ cells $)$ in 24 well multiwell culture plates in the presence or absence of various BMPs $(30-100 \mathrm{ng} / \mathrm{ml}$; generously supplied by Genetics Institute, Cambridge, MA). Cultures contained basic FGF (bFGF) (30 ng/ml; Collaborative Biomedical Products, Bedford, MA) to maintain a level of precursor division and differentiation similar to that observed in vivo and in explant cultures. We find that in the absence of bFGF E13-E14 mouse neocortical precursors differentiate to abnormally high levels (50-70\%; TUJ1- and MAP-2-positive) within $1 \mathrm{~d}$ in vitro (DIV). Cells were cultured for 1-4 DIV and then fixed with $4 \%$ paraformaldehyde for $30 \mathrm{~min}$ at room temperature. Fixed cells on coverslips were washed in PBS and then preblocked in 5\% normal goat serum for 30 min followed by incubation with anti-MAP-2 (1:1400; Boehringer Mannheim, Indianapolis, IN) for $1 \mathrm{hr}$ at room temperature. After washing in PBS, rhodamine-conjugated goat anti-mouse secondary antibody (1:200; Jackson ImmunoResearch, West Grove, PA) was applied. For 5-bromo-2'-deoxyuridine (BrdU) immunohistochemistry, cultures were exposed to $0.5 \mu \mathrm{M}$ BrdU for the last $1 \mathrm{hr}$ of culture to label cells in $\mathrm{S}$ phase. Cells were post-fixed with $70 \% \mathrm{EtOH}$, heated to $65^{\circ}$, treated with acid $(2 \mathrm{~N} \mathrm{HCl})$, then preblocked with $5 \%$ horse serum, and incubated with anti-BrdU (1:200). Cells were counterstained with 4,6-diamidino-2phenylindole (DAPI) (5 mM; Sigma, St. Louis, MO) to visualize nuclei, were washed, and then were mounted in gel mount (Biomeda, Foster City, CA) and imaged with a cooled CCD camera attached to a Nikon Optiphot fluorescence microscope. Total cellular counts were obtained by counting 20 continuous fields of view of each coverslip $(\sim 250-300$ cells) from seven individual culture wells for each condition. Results are presented as the mean \pm SEM. Neurite length was measured using a macro program in National Institutes of Health Image.

Explant cultures. Explants were prepared from E14 mouse neocortex and cultured on polycarbonate membrane in L15 medium (Sigma) with $30 \mathrm{~mm}$ glucose, $25.8 \mathrm{~mm} \mathrm{NaHCO}_{3}, 1 \% \mathrm{~N}_{2}$ supplement (Life Technologies-BRL), penicillin-streptomycin, and $1 \mathrm{~mm}$ glutamine at $37^{\circ}$ in a humidified, $5 \% \mathrm{CO}_{2}$ atmosphere. Affi-Gel Blue Gel beads (Bio-Rad, Hercules, CA) were soaked with $10 \mu \mathrm{l}$ of BMP-4 protein solution at 2 $\mu \mathrm{g} / \mathrm{ml}$ in PBS containing $0.1 \%$ bovine serum albumin (BSA) (BSA/PBS) in a microfuge tube for $1 \mathrm{hr}$ at $37^{\circ}$. The BSA/PBS solution was used as a control. Explants were exposed to $1 \mu \mathrm{M}$ BrdU for the last $2 \mathrm{hr}$ of culture to label cells in $\mathrm{S}$ phase. Explants were fixed with $4 \%$ paraformaldehyde, and 10-12 $\mu \mathrm{m}$ cryostat sections were processed for TUJ1 and BrdU immunofluorescence with anti- $\beta$-tubulin (1:200; Babco, Richmond, CA) and anti-BrdU (1:200; Vector Laboratories, Burlingame, CA). For BrdU immunocytochemistry, sections were first heated to $65^{\circ}$, treated with pepsin $(0.1 \mathrm{mg} / \mathrm{ml})$ and acid $(2 \mathrm{~N} \mathrm{HCl})$, then preblocked with $5 \%$ horse serum, and incubated with anti-BrdU (1:200). Secondary antibodies and image capturing were as described above.

Virus construction and production. $\triangle \mathrm{mBMPR}$ (mTFR11-45 del 21) plasmid contained a $3{ }^{\prime}$-nested deletion clone of mTFR11-45 (generously 
A

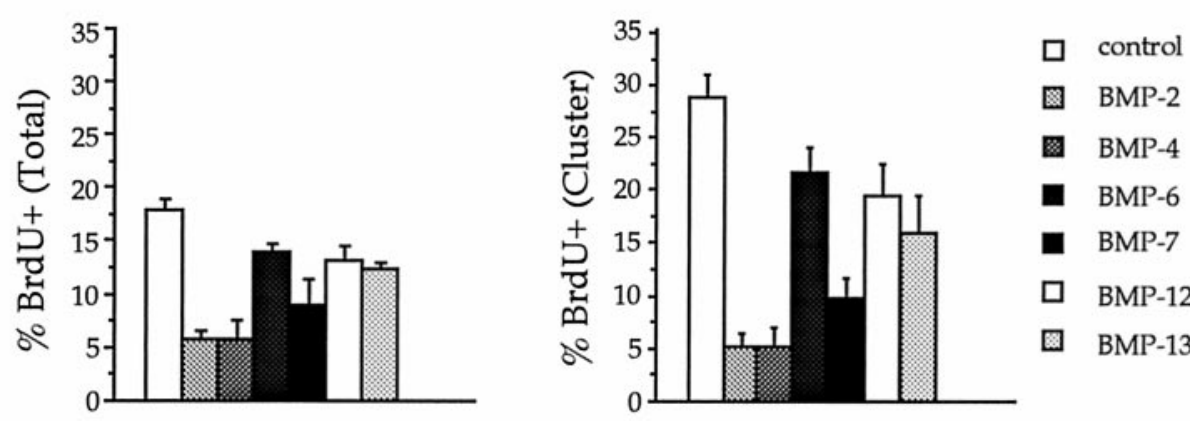

B

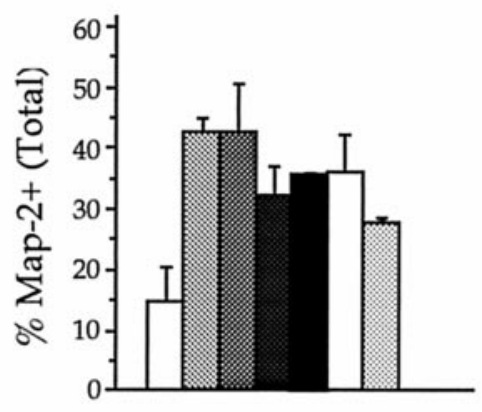

C

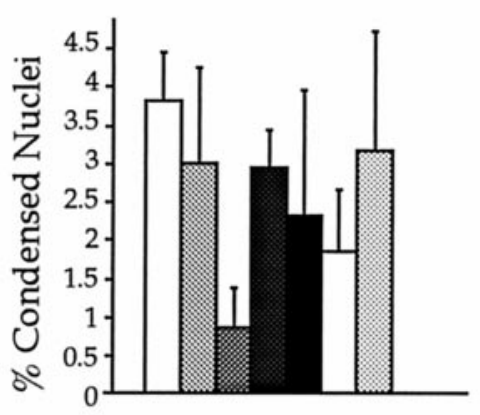

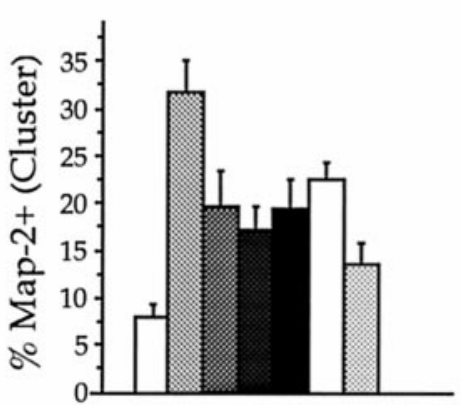

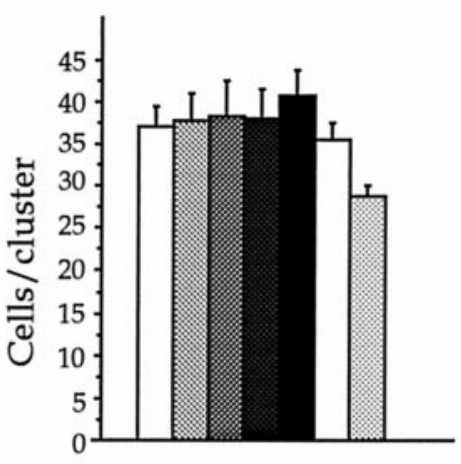

Figure 2. BMPs promote neuronal differentiation and inhibit BrdU incorporation in E12-E13 neocortical precursors. $A$, BMPs from three factor subgroups, the Dpp group (BMP-2 and BMP-4), the 60A group (BMP-6 and BMP-7), and the GDF group (BMP-12 and BMP-13) were applied to cell cultures at $30 \mathrm{ng} / \mathrm{ml}$. These growth factors decrease BrdU incorporation after only 1 DIV. The effect was significant at $p<0.01$ compared with control when expressed as the BrdU incorporation percentage in the total population (left; ANOVA; $n=7$ ). It also shows a significant difference when expressed as the BrdU percentage per cluster (right; $p<0.001 ; n=7$ ). BMP-2 and BMP-4 led to the greatest decrease in the percentage of BrdU-incorporating cells. BMP-7 had effects comparable to those of BMP-2 and BMP-4. B, BMPs $(30 \mathrm{ng} / \mathrm{ml})$ promote neuronal differentiation as measured by the percentage of total cells that express MAP-2 (left $; p<0.01 ;$ ANOVA; $n=7$ ) or by the MAP-2 percentage per cluster (right; $p<0.001 ; n=7$ ). BMP-2 and BMP-4 led to the greatest increase in MAP-2-immunopositive cells. $C$, The percentage of condensed nuclei in the total cell population (left) and the survival of cells per cluster (right) show no statistical difference between control and BMP-treated cell cultures. supplied by A. Suzuki, Hokkaido University). BamHI sites were added to $\triangle \mathrm{mBMPR}$ by PCR, the products were digested with Bam HI, and the resulting $670 \mathrm{bp}$ fragment was ligated into the $B g l \mathrm{II}$ site of pSap retroviral plasmid vector. The resulting plasmid, DEL, was cotransfected with pcDNA3 into $\varphi 2$ packaging cells. After 2-3 d, the medium was changed to selective medium with G418 at $1 \mathrm{mg} / \mathrm{ml}$, and $10 \mathrm{~d}$ later supernatant was recovered and concentrated by centrifugation to obtain a virus titer of $\sim 1.6 \times 10^{6} \mathrm{cfu} / \mathrm{ml}$. The titer of control virus DAP was $\sim 6 \times 10^{6} \mathrm{cfu} / \mathrm{ml}$.

To confirm that the DEL construct was capable of expressing a truncated BMP receptor, we performed BMP binding assays. The wild-type BMP receptor mTFR11/hALK3 was subcloned into the pSap retroviral plasmid vector as a positive control. This control plasmid, DEL, and pSap were each transfected into COS-1 cells, and binding assays were performed with ${ }^{125}$ I-labeled BMP-4 ( ${ }^{125}$ I-BMP-4) $72 \mathrm{hr}$ after transfection (Frolik et al., 1984). Binding assays were performed in quadruplicate with either ${ }^{125}$ I-BMP-4 alone or ${ }^{125}$ I-BMP-4 and a 30-fold molar excess of unlabeled BMP-4 to determine nonspecific binding. The cells transfected with either DEL or mTFR11/hALK3/pSap had approximately fivefold greater specific binding to BMP-4 than did cells transfected with pSap. The DEL construct, therefore, expresses a BMP receptor. To test the effectiveness of DEL in blocking BMP activity, we devised a functional assay with NIH3T3 cells. When 3T3 cells reached confluence, they were split at 1:20 on $12 \mathrm{~mm}$ coverslips coated with protamine $(1 \mathrm{mg} / \mathrm{ml}$; Sigma) and were grown in $4 \%$ fetal bovine serum in PBS with penicillinstreptomycin. Five microliters of either DAP or DEL were used to infect 3 T3 cells (cell:cfu of $\sim 1)$, and BMP-4 $(100 \mathrm{ng} / \mathrm{ml})$ was applied to the cells everyday for $3 \mathrm{~d}$, after which the cells were processed for alkaline phosphatase staining. Infected cells were counted in 60 continuous fields of view of each coverslip ( $\sim 200-600$ cells). This bioassay was performed three times, and in each experiment BMP-4 caused a significant decrease in the number of 3T3 cells in the DAP-infected cells (20-68\% decrease) but not in the DEL-infected cells.

Infection of explants. Ten microliters of DAP or DEL retrovirus were added to the explants prepared as described above. FGF $(10 \mathrm{ng} / \mathrm{ml})$ was added to the medium to increase the number of proliferating cells and thereby to increase the amount of infection; retrovirus can only infect actively cycling cells. After 3 d in vitro, explants were fixed with $4 \%$ paraformaldehyde, sectioned transversely at $10-15 \mu \mathrm{m}$, and processed for alkaline phosphatase staining (Fields-Berry et al., 1992). Migration distance and process length of the infected cells were measured with National Institutes of Health Image. Migration distance was defined as the shortest radial distance from the VZ surface to the center of the infected cell, and process length was determined for both apical and basal processes. For a clonal analysis in explant cultures, clones were defined with a spatial criteria. As in vivo, $3 \mathrm{~d}$ after infection there is limited clonal dispersion, and clones were defined as groups of one to eight cells that were clearly separated from other infected cells by at least $500 \mu \mathrm{m}$. Cells in a clone were grouped into two groups, the VZ or the intermediate zone (IZ) and cortical plate (CP), according to their radial position in the explant. For double labeling with alkaline phosphatase and MAP-2 immunoactivity, explants were cultured as described above and mechanically dissociated, and plated cells were processed for alkaline phosphatase staining as described above and for MAP-2 immunocytochemistry as described above. After alkaline phosphatase staining, explants were incubated in $5 \%$ normal goat serum, followed by incubation in antiMAP-2 antisera (1:1400) for $1 \mathrm{hr}$ at room temperature; the primary 


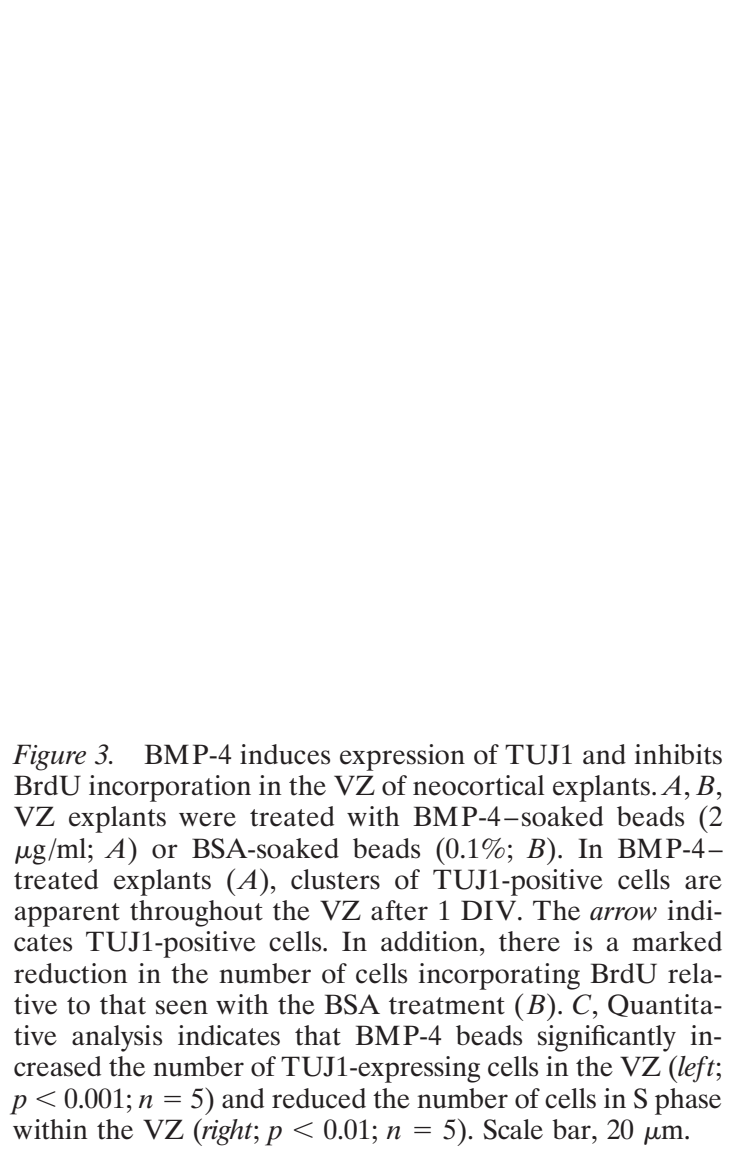

Figure 3. BMP-4 induces expression of TUJ1 and inhibits BrdU incorporation in the $\mathrm{VZ}$ of neocortical explants. $A, B$, Z explants were treated with BMP-4-soaked beads $(2$ treated explants $(A)$, clusters of TUJ1-positive cells are apparent throughout the VZ after 1 DIV. The arrow indicates TUJ1-positive cells. In addition, there is a marked reduction in the number of cells incorporating BrdU relacreased the number of TUJ1-expressing cells in the VZ (left; $p<0.001 ; n=5$ ) and reduced the number of cells in $\mathrm{S}$ phase

antibody was detected with rhodamine-conjugated goat anti-mouse secondary antibody (1:200). MAP-2 immunofluorescence in alkaline-phosphatase-stained cells was visible as a bright fluorescent signal shining through a broken boarder of alkaline phosphatase staining. In this way, alkaline phosphatase-positive cells that were also MAP-2-positive could be easily distinguished from alkaline phosphatase-positive cells that were MAP-2-negative.

Infection of dissociated cell cultures. Twenty microliters of DAP or DEL retrovirus were added to the dissociated cell cultures prepared as described above. Briefly, E13 telencephalons were removed and dissociated. Cells were plated on poly-D-lysine- and laminin-coated $12 \mathrm{~mm}$ coverslips $\left(\sim 4 \times 10^{5}\right.$ cells $)$ in 24 well multiwell culture plates in $500 \mu \mathrm{l}$ of culture medium. Virus was added at the time of plating. After $24 \mathrm{hr}$ in vitro, BMP-4 $(30 \mathrm{ng} / \mathrm{ml})$ or BDNF $(50 \mathrm{ng} / \mathrm{ml})$ was applied to cultured cells. After another $24 \mathrm{hr}$, cells were fixed with $4 \%$ paraformaldehyde and processed for alkaline phosphatase staining (Fields-Berry et al., 1992). The total process length of infected cells was measured with a macro in National Institutes of Health Image.

$B M P-2$ and BMP-4 immunocytochemistry. Freshly removed E13-E16 mouse telencephalons were snap frozen in isopentane, precooled in liquid nitrogen, and stored at $-70^{\circ} \mathrm{C} ; 10 \mu \mathrm{m}$ frozen sections were collected on Superfrost Plus slides and air dried. For immunocytochemistry, frozen sections were washed in PBS and then preincubated for $30 \mathrm{~min}$ in $5 \%$ goat serum followed by incubation in BMP-2 and BMP-4 antisera (1:200; generously supplied by Genetics Institute) for $2 \mathrm{hr}$ at room temperature. After washes in PBS for $30 \mathrm{~min}$ at room temperature, the primary antibody was detected with rhodamine-conjugated goat antimouse secondary antibody (1:200; Jackson ImmunoResearch). Sections were counterstained with DAPI ( $5 \mathrm{~mm}$; Sigma) to visualize nuclei. Slides were coverslipped with gel mount, and images were captured with a Nikon Optiphot configured for epifluorescence with a cooled CCD camera (Photometrics).

Immunoblot analysis. Purified recombinant human BMPs (150 ng; provided by Genetics Institute) were suspended in sample buffer (100 mM Tris, 4\% SDS, $20 \%$ glycerol, $\mathrm{pH}$ 6.8, and bromophenol blue). Samples and prestained molecular weight markers (Bio-Rad) were separated in SDS-polyacrylamide gels (15\%). Protein was then electrophoretically transferred to a polyvinylidene difluoride membrane (Millipore, Bed-
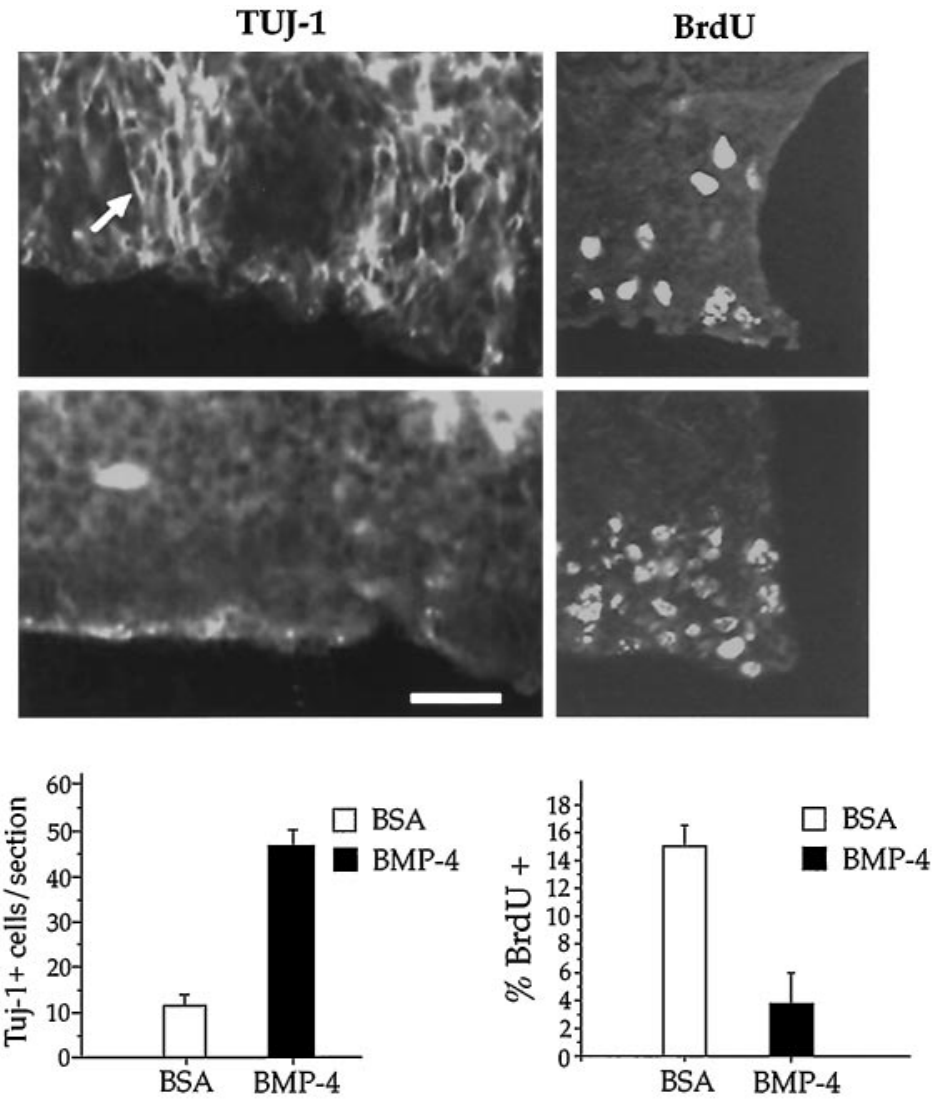

ford, MA). After blocking with 4\% BSA, the membrane was incubated in anti-BMP-2/4 monoclonal antibody (1:150; Genetics Institute). The blots were then incubated with a horseradish peroxidase-conjugated goat anti-mouse secondary antibody (1:500) and developed by a chemiluminescent detection system described by the manufacturer (KPL, Gaithersburg, MD).

\section{RESULTS \\ BMPs promote differentiation of neocortical neuroepithelial cells}

To test the hypothesis that BMPs promote the differentiation of neocortical neurons, we first conducted experiments using dissociated cell cultures of neocortical neuroepithelial cells. For these experiments we used the "cluster culture" first described by Ghosh and Greenberg (1995). Briefly, explants of E13 mouse dorsal telencephalon were mechanically dissociated and plated in serum-free medium in a manner that results in cultures containing a mixture of small groups or clusters of cells (20-70 cells) and isolated cells. In the presence of bFGF, cells in clusters maintain a level of proliferation and a rate of differentiation similar to that in in vivo conditions. BMPs from three factor subgroups, the Dpp group (BMP-2 and BMP-4), the 60A group (BMP-6 and BMP7 ), and the growth differentiation factor (GDF) group (BMP-12 and BMP-13) were applied to cell cultures at a concentration of $30 \mathrm{ng} / \mathrm{ml}$. After $24 \mathrm{hr}$ of treatment, BMPs did not cause a significant change in either the number of cells present in each cluster or in the percentage of condensed nuclei in the culture (Figs. $1 C, 2 C$ ). Thus, BMPs have no effect on the survival of neocortical precursors after 1 DIV. In contrast, BMPs caused a significant decrease in the percentage of cells that incorporate BrdU after 1 DIV $(n=7 ; p<0.01)$ and increased the percentage 
A

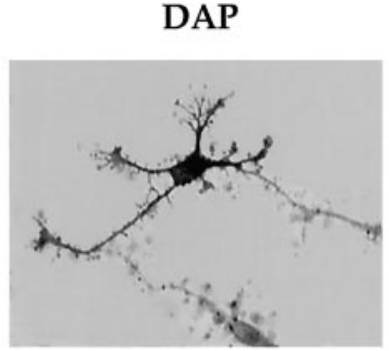

B

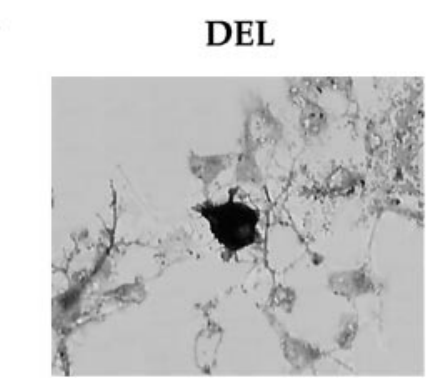

C

DEL

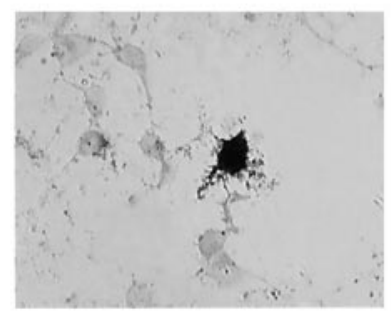

DAP+BMP-4 (30ng/ml)

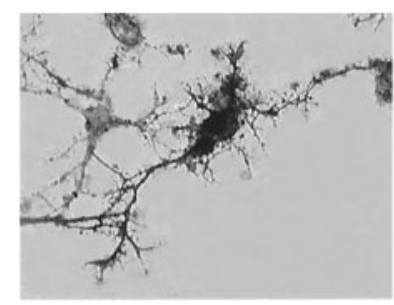

DEL+BMP-4 (30ng/ml)

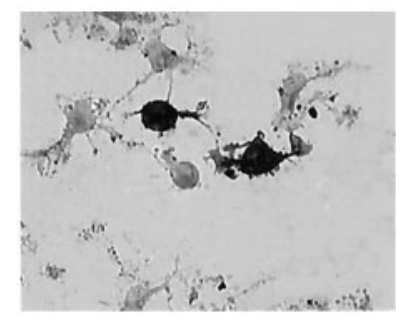

DEL+BDNF (50ng/ml)

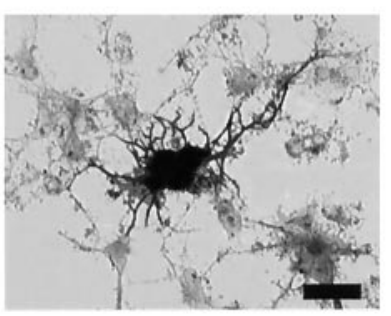

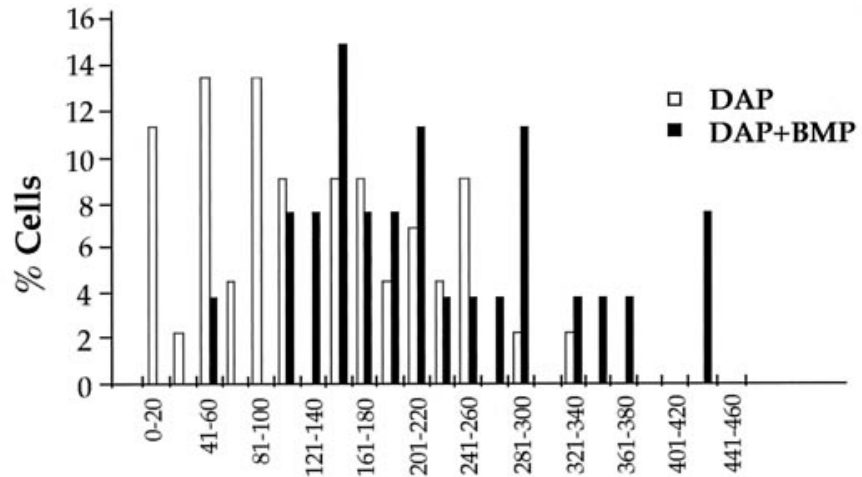
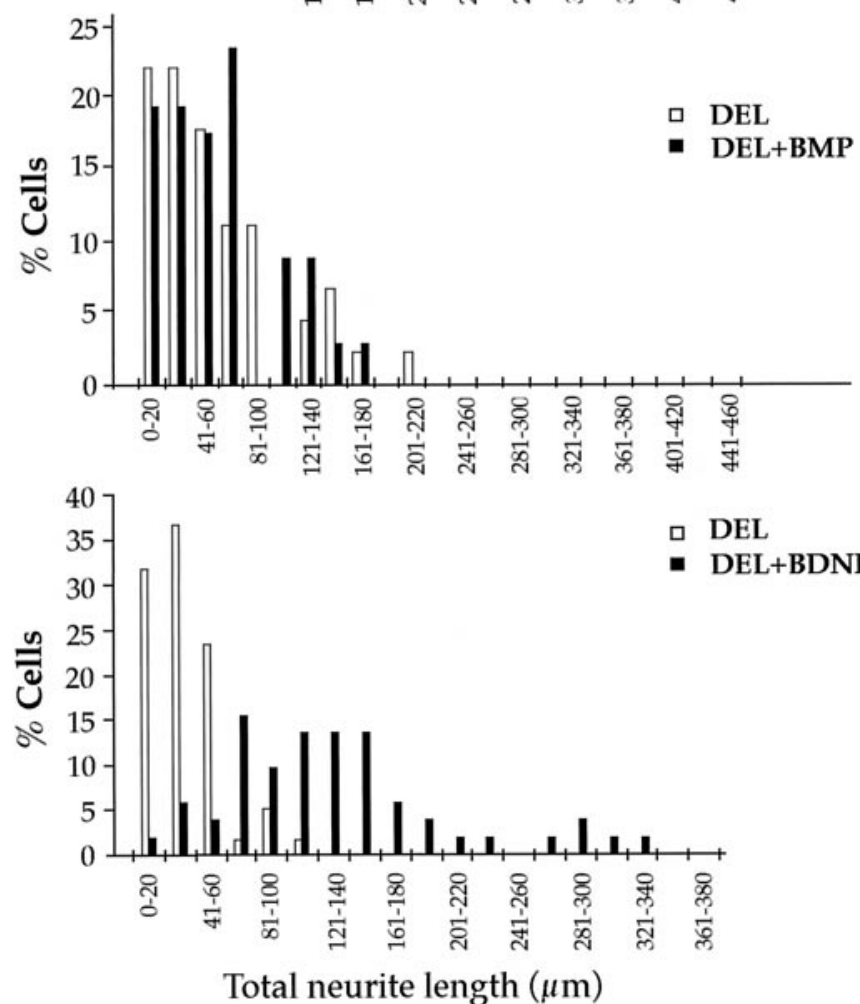

Figure 4. Dominant-negative BMP-4 receptor affects normal neuronal differentiation in dissociated cell culture. $A$, Cells infected with DAP virus bear neurite trees typical of normal differentiating neurons. When cultured in the presence of BMP-4 $(30 \mathrm{ng} / \mathrm{ml})$, neurites elaborate more extensively. $B$, Cells infected with the DEL virus do not extend neurites, even after the application of BMP-4 $(30 \mathrm{ng} / \mathrm{ml})$. The quantitative analysis shown in $B$ indicates that the distribution of neurite lengths shifts after BMP-4 treatment for $24 \mathrm{hr}$. $C$, BDNF treatment of DEL-infected precursors induces an increase in neurite length indicating that the truncated receptor introduced by DEL is not nonspecifically blocking differentiation. Scale bar, $20 \mu \mathrm{m}$.

of cells, in both the entire culture and in clusters, that express MAP-2 $(n=7 ; p<0.01)$ and TUJ1 $(n=3 ; p<0.01)$ (Figs. $1 A, B$, $2 A, B)$. After $24 \mathrm{hr}, \mathrm{BMP}-2$ and BMP-4 led to the greatest decrease in BrdU-incorporating cells and also to the greatest increase in MAP-2-immunopositive cells (Figs. 1, 2A,B). As an additional measure of enhanced neural differentiation, we found that BMP-4 significantly increases neurite length in MAP-2positive cells. After 3 DIV, cells in cultures treated with BMP-4 had neurons with mean neurite lengths of $326 \mu \mathrm{m} /$ neuron $(n=$ 17), whereas neurons in untreated cultures had mean neurite lengths of $202 \mu \mathrm{m} /$ neuron $(n=20)$.

\section{BMP promotes differentiation and inhibits BrdU incorporation in the $\mathbf{V Z}$}

In addition to dissociated cell culture, we used explant cultures of E14 dorsal telencephalon to test whether BMP-4 added to the VZ surface can induce differentiation of cells in the VZ. For these experiments we applied beads that had been soaked in either BMP-4 $(2 \mu \mathrm{g} / \mathrm{ml})$ or BSA $(0.1 \%)$ to the VZ surface of E14 neocortical explants. We hypothesized that BMP-4 would both induce expression of TUJ1 (an early neural differentiation marker that labels some cells within the VZ) and reduce the number of cells that re-enter the cell cycle within the VZ. As shown in Figure 3, after only 1 DIV, the BMP-4 beads induced TUJ1 expression in many cells arranged in radial clusters within the $\mathrm{VZ}$ $(p<0.001 ; n=5)$. The speed of induction $(24 \mathrm{hr})$, the increase in number, and the orientation of these cells would eliminate the possibility that the increase in TUJ1 cells arose by induced migration of existing TUJ1-positive cells in the VZ. In addition, BMP-4 reduced the number of cells in $\mathrm{S}$ phase within the VZ $(p<0.01 ; n=5)$. Together, these results indicate that BMP is not at saturating concentrations at the VZ surface and that 
Figure 5. Dominant-negative BMP-4 receptor alters the development of cortical precursors in situ. $A, B$, Cells infected with DAP and grown in culture for $3 \mathrm{~d}$. Cells have migrated away from the VZ surface and have extended processes. $C-E$, Cells infected with DEL and grown in culture for $3 \mathrm{~d}$. In contrast to cells infected with DAP, most cells infected with the DEL virus are confined to the VZ and do not extend apical processes. Scale bar: $A-C, 20$ $\mu \mathrm{m} ; D, E, 10 \mu \mathrm{m}$.
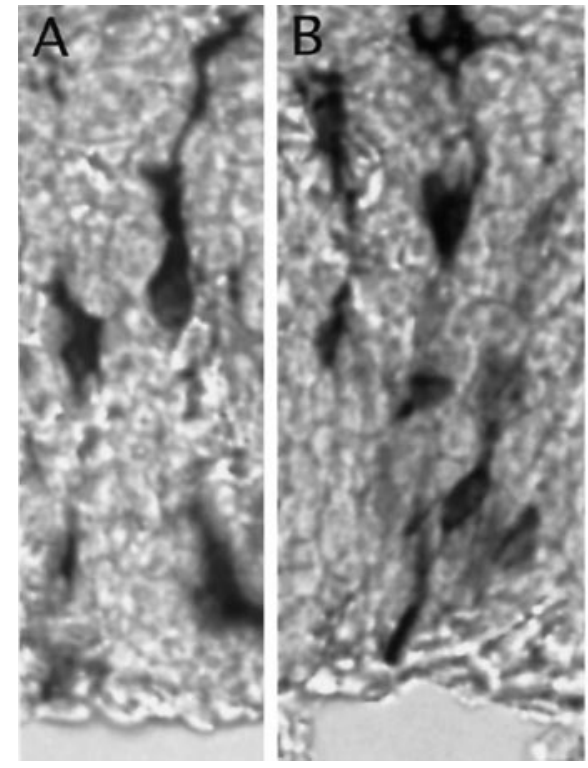
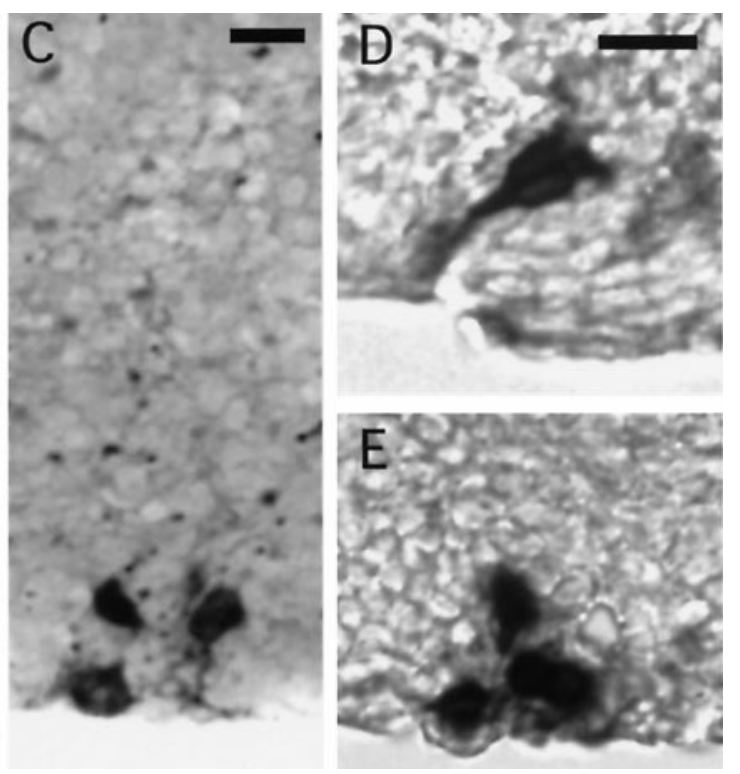

BMP-4 rapidly (within 1 DIV) triggers the initiation of neuronal differentiation.

\section{Truncated BMP receptor blocks both migration out of the $\mathbf{V Z}$ and neuronal differentiation}

To determine the role of endogenous BMP signaling and to determine whether the effects of BMP are direct on neocortical precursors, we used retrovirus-mediated gene transfer. Two replication-incompetent retroviruses were used in these experiments. A control virus, DAP (Fields-Berry et al., 1992), contains a sequence for alkaline phosphatase, and DEL contains a sequence encoding a truncated type I BMP receptor downstream of the viral long terminal repeat in addition to sequence encoding alkaline phosphatase downstream of an internal SV40 promoter. The truncated BMP receptor (truncated mTFR11/hALK3) contains only the extracellular and transmembrane region of the BMP receptor and has been shown by Suzuki et al. (1994) to block BMP-4 signaling in Xenopus embryos. Furthermore, we have determined, with binding assays (see Materials and Methods), that DEL expresses BMP-4 receptor.

DAP and DEL virus were used to infect precursor cells in dissociated cell culture. The DAP-infected cells bear neurite arbors typical of differentiating neurons (Fig. 4A). Application of BMP-4 (30 ng/ml) promotes neurite elaboration (Fig. 4A) in DAP-infected cells; however, precursors infected with the DEL virus did not extend neurites either in the presence or absence of BMP-4 (Fig. 4B). To determine whether the truncated receptor blocked neurite elaboration by blocking BMP signaling or by nonspecifically blocking differentiation, we tested the effects of BDNF treatment on DEL-infected precursors. In contrast to BMP treatment, infection by the DEL retrovirus did not block BDNF from inducing an increase in neurite length (Fig. 4C). Thus, the DEL retrovirus does not nonspecifically block neuronal differentiation. Moreover, because DEL-infected cells (Fig. $4 B, C$ ) have less neurite length than do DAP-infected cells (Fig. $4 A$ ) in untreated cultures, endogenous BMP signaling in these cultures seems to promote the elaboration of neurites.

To test whether BMP signaling is required for the normal progression of neocortical precursors to migrate out of the $\mathrm{VZ}$ and differentiate in situ, we used explant cultures of neocortex. Cells in explants, similar to cells in vivo, continue to proliferate over several days and to migrate out of the ventricular zone into the intermediate zone and cortical plate where they elaborate neurites (Burrows et al., 1997). Most cells in clones infected with DAP (Figs. $5 A, B, 6 A, B$ ) migrated from the ventricular surface after 3 DIV, spread throughout the width of the cortical explant, and extended both apical and basal processes. In contrast, most cells infected with the DEL virus were primarily confined to the $\mathrm{VZ}$ and did not extend apical processes (Figs. $5 C-E, 6 A, B)$. Cells infected with the DEL virus migrated from the VZ surface (16 \pm $19 \mu \mathrm{m})$ a shorter distance than did cells infected with DAP (31 \pm $22 \mu \mathrm{m})$. Some DEL-infected cells $(21 \%)$, however, migrated out of the VZ similarly to DAP-infected cells. The appearance of these apparently unaffected cells is consistent with the life cycle of the retrovirus that integrates into the genome at the beginning of M phase (Roe et al., 1993). Cells that are destined to migrate from the $\mathrm{VZ}$ and not divide again should not be affected by the DEL virus because in these cells the dominant-negative receptor would not be expressed until after the cell had migrated away from the VZ surface. In addition, most cells infected with DEL, unlike DAP-infected cells, were round in appearance and had little or no process. As shown in Figure $6 B$, process length was on average $10 \pm 16 \mu \mathrm{m}$ for DEL-infected cells and $23 \pm 21 \mu \mathrm{m}$ for DAP-infected cells. To determine whether the DEL infection causes an inhibition of neuronal differentiation as measured by MAP-2 expression, we conducted experiments in which explants were infected and cultured as above, and then cells were dissociated, plated onto slides, and double labeled for alkaline phosphatase and MAP-2 immunoreactivity. MAP-2 was expressed in $17 \%$ of the DEL-infected cells, whereas $45 \%$ of DAP-infected cells expressed MAP-2 $(n=4 ; p<0.01)$.

A clonal analysis of DAP and DEL clones is shown in Figure $6 C$. There is no significant difference between the average clone size for DAP and DEL. This indicates that blocking BMP signaling does not increase cell death or proliferation. In contrast to clone size, there is a significant change in the location of cells within clones in developing neocortex. As shown in Figure $6 C$, there are significantly more members of clones located in the $\mathrm{VZ}$ in the DEL clones compared with the DAP clones $(p<0.001$; $n=19)$. These results suggest that BMP signals directly received 
A

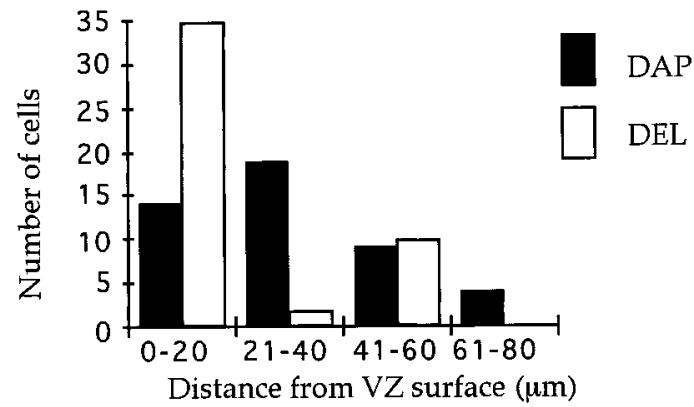

B

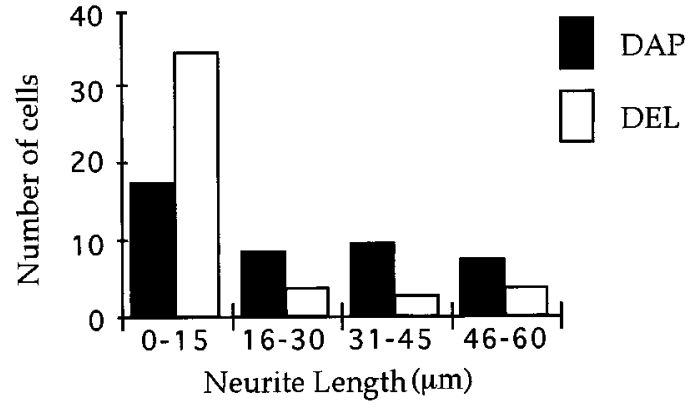

C

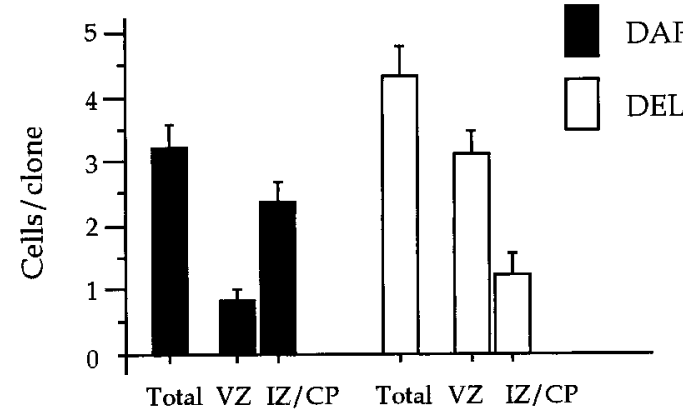

Figure 6. Truncated BMP-4 receptor blocks migration and the differentiation of cortical precursors. $A$, Histogram of the distance migrated from the VZ surface for cells infected with DAP and DEL. Most of the DEL-infected cells are within $20 \mu \mathrm{m}$ of the VZ surface. $B$, Histogram of the length of apical and basal processes extending from cells infected with DAP and DEL. $C$, Clonal analysis showing similar clone sizes in both DAP- and DEL-infected clones but a change in the distribution of cells within clones in the developing neocortex. Significantly more cells in the DEL than in the DAP clones are located in the VZ, and significantly more cells in the DAP than in the DEL clones are located in the IZ and CP $(p<0.001 ; n=19)$.

by neocortical precursors within the $\mathrm{VZ}$ promote the migration of postmitotic cells out of the VZ.

\section{BMPs are localized to the VZ surface}

The dominant-negative receptor results described above suggest that endogenous BMP signaling occurs within the VZ. This further predicts that BMP protein may be localized within the VZ. We initially used RT-PCR, with degenerate oligonucleotides that identify TGF- $\beta$ superfamily members (Basler et al., 1993), to detect BMP expression in mouse telencephalon. We sequenced 20 clones and found that, out of the 20 clones, two contained sequence matching BMP-2, two matched BMP-4, one matched BMP-5, and one matched BMP-7. To determine whether BMP protein is present within the VZ, we used fluorescence immunocytochemistry with an antibody specific to BMP-2 and BMP-4, hr3b2 mAb (Yoshikawa et al., 1994a,b), on freshly frozen tissue sections of E12-E16 mouse neocortex (Fig. 7). To test the spec- ificity of hr3b2 with respect to BMPs, we performed a Western immunoblot. As shown in Figure 8, the BMP-2/4 antibody recognizes BMP-2 and BMP-4 protein; however it does not recognize the other BMPs tested, including BMP-6, BMP-7, BMP-12, and BMP-13. These results are consistent with previous reports (Wozney et al., 1988, 1990; Wozney, 1989; Bostrom et al., 1995) showing the specificity of this antibody for BMP-2 and BMP-4. When used in immunocytochemistry, hr3b $2 \mathrm{mAb}$, as shown in Figure $7 A$, resulted in staining limited to and often surrounding cells at the VZ surface. This staining was blocked by preabsorbing the antibody with recombinant BMP-4 (Fig. $7 B$ ). The discrete punctate extracellular staining pattern observed in the $\mathrm{VZ}$ is nearly identical to the staining pattern that has been reported for bone tissue using this same antibody (Gannon et al., 1997). Whether this punctate staining represents BMP bound to receptor clusters or BMP released at concentrated points is unknown. Nevertheless, this punctate staining made it possible to quantify the staining throughout the width of E16 cortex. As shown in Figure $7 C$, immunopositivity was most concentrated within 20 $\mu \mathrm{m}$ of the $\mathrm{VZ}$ surface, and no staining of similar density was found in any other layers, including the intermediate zone, the cortical plate, and the marginal zone. The cell type that expresses BMP-2 and BMP-4 at the VZ surface is not known at this time; however, BMP-6 has been shown to be expressed specifically by radial glial cells (Schluesener and Meyermann, 1994).

\section{DISCUSSION}

In this paper we demonstrate that BMPs promote neuronal differentiation of neocortical precursors and that a dominantnegative BMP receptor blocks neuronal differentiation and migration of neocortical precursors from the VZ. These findings extend the known roles of BMPs in neural development and suggest that BMPs promote the generation of neocortical neurons from within the VZ.

\section{BMP acts directly}

Four pieces of evidence support the idea that BMPs act directly on neocortical precursors in the VZ. First, the effects of BMP are rapid. There is a significant increase in neuronal differentiation within $24 \mathrm{hr}$ of cell culture. Second, BMP-2/4 protein is present in highest amounts at the VZ surface where it can only come in contact with either radial glial cells or neural precursors. The localization of ligand stands in contrast to the widespread expression of BMP receptor throughout all layers of the developing neocortex (Dewulf et al., 1995; Söderström et al., 1996). Third, in the explant experiments, BMP-4 was applied to the VZ surface with beads. The best evidence of a direct effect of BMP, however, comes from the results with the dominant-negative receptor in both dissociated cell culture and explant culture. Because the infection rates are between 1 and $3 \%$ in our dissociated cultures, and even less in explant cultures (3-20 clones/explant), and because the truncated receptor blocks BMP-induced differentiation, the DEL virus must block endogenous signals acting directly on precursors.

\section{Differential control of differentiation and proliferation}

The addition of BMP to cultures decreases the number of cells that re-enter the cell cycle and increases the number of cells that differentiate. Blocking BMP signaling, however, does not result in an increase in cell proliferation. In both the dissociated cell culture and explant cultures, clones infected with DEL are not 


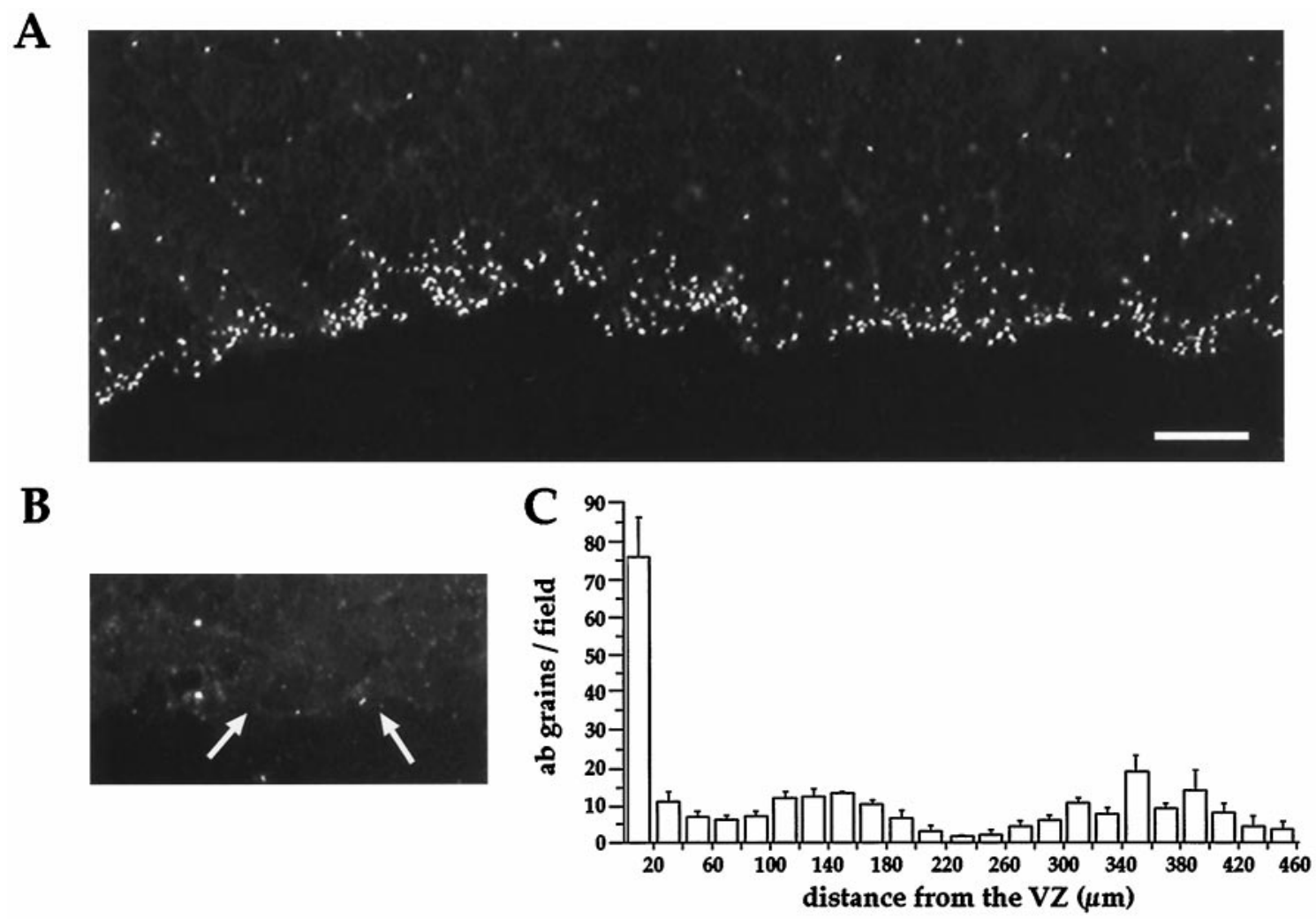

Figure 7. BMP protein is concentrated at the VZ surface. A, Immunofluorescent image of an E16 ventricular zone stained with an antibody specific to BMP-2 and BMP-4 is shown. Cells were not permeabilized with Triton or fixative, and the punctate staining for BMP is limited to and surrounding cells at the VZ surface. B, Preabsorption of the antibody with excess BMP-4 protein eliminates staining at the VZ surface (arrows indicate the edge of the VZ surface). $C$, A quantitative analysis of staining shows BMP protein is concentrated at the VZ surface. The histogram shows the number of antibody grains for $20-\mu \mathrm{m}$-wide bins, tangential to the $\mathrm{VZ}$ surface, through the width of the cortical mantle. The maximum number of antibody grains was in the first $20 \mu \mathrm{m}$ from the VZ surface. Scale bar, $20 \mu \mathrm{m}$.

\section{BMP protein (150ng)}

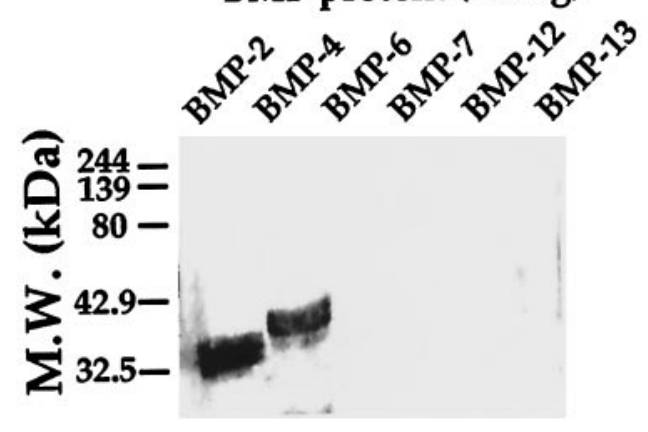

Figure 8. Specificity analysis of BMP-2/4 antibody in immunoblot experiments with recombinant human BMPs. BMP-2/4 antibody is specifically reactive with BMP-2 and BMP-4 but not with BMP-6, BMP-7, BMP-12, or BMP-13; $150 \mathrm{ng}$ of protein was loaded in each lane. The bands correspond to $\sim 32 \mathrm{kDa}$. The positions of molecular weight markers are indicated on the left.

significantly larger. The fate of the infected cells that do not undergo neural differentiation is unknown. However, preliminary experiments indicate that they do not express glial markers. Future in vivo experiments are underway to determine the fates of these cells. Nevertheless, these results indicate that added BMP promotes differentiation at the expense of re-entry into the cell cycle; however, blocking BMP is not sufficient to promote reentry into the cell cycle. Therefore, controls other than limiting
BMP signaling are restricting neocortical precursors from reentering the cell cycle. Such controls could include a decrease in responsiveness to bFGF (Lillien and Cepko, 1992), a decrease in gap junction coupling (Bittman et al., 1997), or an increase in p27 activity in neocortical precursors (Lee et al., 1996).

\section{Changing responses to BMPs throughout development}

BMPs play many roles throughout development of the nervous system. In early embryogenesis, BMPs are inhibitors of neuroectoderm formation (Wilson and Hemmati-Brivanlou, 1995; Hemmati-Brivanlou and Melton, 1997), whereas in latter neural differentiation, BMPs promote the differentiation of both neural cell types (Varley and Maxwell, 1996) and astroglial cells (Gross et al., 1996). The change in responsiveness to BMPs throughout development is clearly evident during the development of neocortex. There are two populations of proliferating precursors in the developing neocortex, VZ cells and SVZ cells. The VZ primarily produces neurons, whereas the SVZ primarily produces glia (Bayer and Altman, 1991). As we have shown here, BMP-4 promotes the differentiation of neurons from the $\mathrm{VZ}$ population, and recently BMPs have been shown to promote the development of astroglial cells from SVZ cells (Gross et al., 1996). The cells of the SVZ arise from cells in the VZ, suggesting that VZ cells undergo a shift in their response to BMPs through corticogenesis. In a recent study it was shown that the amount of EGF receptor expression critically determines the transition from the $\mathrm{VZ}$ population of cells to the SVZ population (Burrows et al., 1997). 
Thus, an increase in EGF signaling may trigger a change in the way cortical precursors respond to BMP signals.

\section{BF-1 may act downstream of BMP in neurogenesis}

Recently, direct genetic evidence has been obtained for the essential involvement of BF-1 in the differentiation of neocortical neurons in vivo. In null mutations of BF-1, forebrain neurons prematurely differentiate, and there is a depletion of the progenitor pool that results in a severely reduced cerebral cortex (Xuan et al., 1995). Therefore, BF-1 normally exerts a negative influence on the differentiation of cortical neurons. In a recent paper by Furuta et al. (1997), BMP-4 has been shown to downregulate BF-1 in the medial telencephalon in early forebrain development. By extrapolation to latter neocortical development, BMP signaling in the VZ may stimulate neuronal differentiation by downregulating BF-1 expression.

\section{Integration with other signals}

Several secreted factors have been shown to alter the development of neocortical precursors. For example, PDGF and NT3 promote neuronal differentiation of neuroepithelial cells after several days in dissociated cell culture (Ghosh and Greenberg, 1995; Williams et al., 1997). FGF-2 has been shown to specify, in a dose-dependent manner, neuronal lineage from cortical stem cells grown in cell culture (Qian et al., 1997). Basic FGF stimulates the division of neocortical precursors (Baird, 1994; Kilpatrick et al., 1995; Temple and Qian, 1995; Gritti et al., 1996), and pituitary-adenylate cyclase-activating peptide ( $\mathrm{Lu}$ and DiCicco-Bloom, 1997) and amino acid neurotransmitters (LoTurco et al., 1995; Antonopoulos et al., 1997) inhibit precursors from re-entering the cell cycle. It is not clear, however, where within the VZ any of these diffusible factors act on neocortical precursors. Future studies on neocortical neuronal differentiation must address which factors are interacting in vivo and in situ to generate neocortical neurons. The interaction of many factors may be necessary to generate the great diversity of neuronal cell types present in the mammalian neocortex.

\section{REFERENCES}

Antonopoulos J, Pappas IS, Parnavelas JG (1997) Activation of the GABA receptor inhibits the proliferative effects of bFGF in cortical progenitor cells. Eur J Neurosci 9:291-298.

Baird A (1994) Fibroblast growth factors: activities and significance of non-neurotrophic growth factors. Curr Opin Neurobiol 4:78-86.

Basler K, Edlund T, Jessell TM, Yamada T (1993) Control of cell pattern in the neural tube: regulation of cell differentiation by dorsalin-1, a novel TGF- $\beta$ family member. Cell 73:687-702.

Bayer SA, Altman J (1991) Neocortical development. New York: Raven.

Bittman K, Owens DF, Kriegstein AR, LoTurco JJ (1997) Cell coupling and uncoupling in the ventricular zone of developing neocortex. J Neurosci 17:7037-7044.

Bostrom MPG, Lane JM, Berberian WS (1995) Immunolocalization and expression of bone morphogenetic protein 2 and 4 in fracture healing. J Orthop Res 13:357-367.

Boulder Committee (1970) Embryonic vertebrate central nervous system: revised terminology. Anat Rec 166:257-262.

Burrows RC, Wancio D, Levitt P, Lillien L (1997) Response diversity and the timing of progenitor cell maturation are regulated by developmental changes in EGFR expression in the cortex. Neuron 19:251-267.

Chun JJM, Shatz CJ (1989) The earliest-generated neurons of the cat cerebral cortex: characterization by MAP2 and neurotransmitter immunohistochemistry during fetal life. J Neurosci 9:1648-1667.

Cobas A, Fairen A, Alvarez-Bolado G, Sanchez MP (1991) Prenatal development of the intrinsic neurons of the rat neocortex: a comparative study of the distribution of GABA-immunoreactive cells and the GABAa receptor. Neuroscience 40:375-397.

Del Rio JA, Soriano E, Ferrer I (1992) Development of GABA- immunoreactivity in the neocortex of the mouse. J Comp Neurol 326:501-526.

Dewulf N, Verschueren K, Lonnoy O, Moren A, Grimsby S, Spiegle KV, Miyazono K, Huylebroeck D, Dijke PT (1995) Distinct spatial and temporal expression patterns of two type I receptors for bone morphogenetic proteins during mouse embryogenesis. Endocrinology 136:2652-2663.

Fields-Berry SC, Halliday AL, Cepko CM (1992) A recombinant retrovirus encoding alkaline phosphatase confirms clonal boundary assignment in lineage analysis of murine retina. Proc Natl Acad Sci USA 89:693-697.

Fishell G, Mason CA, Hatten ME (1993) Dispersion of neural progenitors within the germinal zones of the forebrain. Nature 362:636-638.

Frolik CA, Wakefield LM, Smith DM, Sporn MB (1984) Characterization of a membrane receptor for transforming growth factor- $\beta$ in normal kidney fibroblasts. J Biol Chem 259:10995-11000.

Furuta Y, Piston DW, Hogan BLM (1997) Bone morphogenetic proteins (BMPs) as regulators of dorsal forebrain development. Development 124:2203-2212.

Gannon FH, Kaplan FS, Lomsted E, Finkel GC, Zasloff MA, Shore E (1997) Bone morphogenetic protein 2/4 in early fibromatous lesions of fibrodysplasia ossificans progressiva. Hum Pathol 28:339-343.

Ghosh A, Greenberg M (1995) Distinct roles for bFGF and NT-3 in the regulation of cortical neurogenesis. Neuron 15:89-103.

Gritti A, Parati EA, Cova L, Frolichsthal P, Galli R, Wanke E, Faravelli L, Morassutti DJ, Roisen F, Nickel DD, Vescovi A (1996) Multipotential stem cells from the adult mouse brain proliferate and self-renew in response to basic fibroblast growth factor. J Neurosci 16:1091-1100.

Gross RE, Mehler MF, Mabie PC, Zang Z, Santschi L, Kessler JA (1996) Bone morphogenetic proteins promote astroglial lineage commitment by mammalian subventricular zone progenitor cells. Neuron 17:595-606.

Hatten ME (1990) Riding the glial monorail: a common mechanism for glial-guided neuronal migration in different regions of the developing mammalian brain. Trends Neurosci 13:179-184.

Heberlein U, Wolff T, Rubin GM (1993) The TGF- $\beta$ homolog dpp and the segment polarity gene hedgehog are required for propagation of a morphogenetic wave in the Drosophila retina. Cell 75:913-926.

Hemmati-Brivanlou A, Melton D (1997) Vertebrate embryonic cells will become nerve cells unless told otherwise. Cell 88:13-17.

Hogan BLM (1996) Bone morphogenetic proteins: multifunctional regulations of vertebrate development. Genes Dev 10:1580-1594.

Kilpatrick TJ, Richards LJ, Bartlett PF (1995) The regulation of neural precursor cells within the mammalian brain. Mol Cell Neurosci 6:2-15.

Kingsley DM (1994) The TGF- $\beta$ superfamily: new members, new receptors, and new genetic tests of function in different organisms. Genes Dev 8:133-146.

Lee MH, Nikolic M, Baptista CA, Lai E, Tsai LH, Massague J (1996) The brain-specific activator p35 allows Cdk5 to escape inhibition by p27Kip1 in neurons. Proc Natl Acad Sci USA 93:3259-3263.

Lee MK, Tuttle JB, Rebhun LL, Cleveland DW, Frankfurter A (1990) The expression and posttranslational modification of a neuron-specific $\beta$-tubulin isotype during chick embryogenesis. Cell Motil Cytoskeleton 17:118-132.

Lein PJM, Guo X, Rueger D, Higgins D (1995) Osteogenic protein-1 induces dendritic growth in rat sympathetic neurons. Neuron 15:597-605.

Liem KFJ, Tremml G, Roelink H, Jessell TM (1995) Dorsal differentiation of neural plate cells induced by BMP-mediated signals from epidermal ectoderm. Cell 82:969-979.

Lillien L, Cepko L (1992) Control of proliferation in the retina: temporal changes in responsiveness to FGF and TGF alpha. Development 115:253-266.

LoTurco JJ, Blanton MG, Kriegstein AR (1991) Initial expression and endogenous activation of NMDA channels in early neocortical development. J Neurosci 11:792-799.

LoTurco JJ, Owens DF, Heath MJS, Davis MBE, Kriegstein AR (1995) GABA and glutamate depolarize cortical progenitor cells and inhibit DNA synthesis. Neuron 15:1287-1298.

Lu N, DiCicco-Bloom E (1997) Pituitary adenylate cyclase-activation polypeptide is an autocrine inhibitor of mitosis in cultured cortical precursor cells. Proc Natl Acad Sci USA 94:3357-3362.

Ma C, Zhou Y, Beachy PA, Moses K (1993) The segment polarity gene hedgehog is required for progression of the morphogenetic furrow in the developing Drosophila eye. Cell 75:927-938. 
Maxwell GD, Reid K, Elefanty A, Bartlett PF, Murphy M (1996) Glial cell line-derived neurotrophic factor promotes the development of adrenergic neurons in mouse neural crest cultures. Proc Natl Acad Sci USA 93:13274-13279.

McConnell S (1988) Development and decision-making in the mammalian cerebral cortex. Brain Res Rev 13:1-23.

Mehler MF, Kessler JA (1995) Cytokines and neuronal differentiation. Crit Rev Neurobiol 9:419-446.

Mehler MF, Mabie PC, Zhang D, Kessler JA (1997) Bone morphogenetic proteins in the nervous system. Trends Neurosci 20:309-317.

Menezes JRL, Luskin MB (1994) Expression of neuron-specific tubulin defines a novel population in the proliferative layers of the developing telencephalon. J Neurosci 14:5399-5416.

Misson JP, Austin CP, Takahashi T, Cepko CL, Caviness Jr VS (1991) The alignment of migrating neural cells in relation to the murine pallial radial glial fiber system. Cereb Cortex 1:221-229.

O'Rourke NA, Dailey ME, Smith SJ, McConnell SK (1992) Diverse migratory pathways in the developing cerebral cortex. Science 258:299-302.

O'Rourke NA, Sullivan DP, Kaznowski CE, Jacobs AA, McConnell SK (1995) Tangential migration of neurons in the developing cerebral cortex. Development 121:2165-2176.

Parnavelas JG, Cavanagh ME (1988) Transient expression of neurotransmitters in the developing neocortex. Trends Neurosci 11:92-93.

Qian X, Davis AA, Goderie SK, Temple S (1997) FGF2 concentration regulates the generation of neurons and glia from multipotent cortical stem cells. Neuron 18:81-93.

Rakic P (1972) Mode of cell migration to the superficial layers of fetal monkey neocortex. J Comp Neurol 145:61-84.

Roe T, Reynolds TC, Yu G, Brown PO (1993) Integration of murine leukemia virus DNA depends on mitosis. EMBO J 12:2099-2108.

Schluesener H, Meyermann R (1994) Expression of BMP-6, a TGF- $\beta$ related morphogenetic cytokine, in rat radial glial cells. Glia 12:161-164.

Schwartz ML, Meinecke DL (1992) Early expression of GABAcontaining neurons in the prefrontal and visual cortices of rhesus monkeys. Cereb Cortex 2:16-37.

Shah NM, Groves AK, Anderson DJ (1996) Alternative neural crest cell fates are instructively promoted by TGF- $\beta$ superfamily members. Cell 85:331-343.

Söderström S, Bengtsson H, Ebendal T (1996) Expression of serine/ threonin kinase receptors including the bone morphogenetic factor type II receptor in the developing and adult rat brain. Cell Tissue Res 286:269-279.

Suzuki A, Thies RS, Yamaji N, Song JJ, Wozney JM, Murakami K, Ueon N (1994) A truncated bone morphogenetic protein receptor affects dorsal-ventral patterning in the early Xenopus embryo. Proc Natl Acad Sci USA 91:10255-10259.
Takahashi T, Nowakowski RS, Caviness Jr VS (1992) BrdU as an S-phase marker for quantitative studies of cytokinetic behaviour in the murine cerebral ventricular zone. J Neurocytol 21:185-197.

Takahashi T, Nowakowski RS, Caviness Jr VS (1995) The cell cycle of the pseudostratified ventricular epithelium of the murine cerebral wall. J Neurosci 15:6046-6057.

Takahashi T, Nowakowski RS, Caviness Jr VS (1996) The leaving or Q fraction of the murine cerebral proliferative epithelium: a general model of neocortical neurogenesis. J Neurosci 16:6183-6196.

Temple S, Qian X (1995) bFGF, neurotrophin, and the control of cortical neurogenesis. Neuron 15:249-252.

Van Eden CG, Mrzljak L, Voorn P, Uylings HBM (1989) Prenatal development of GABAergic neurons in the cortex of the rat. J Comp Neurol 289:213-227.

Varley JE, Maxwell GD (1996) BMP-2 and BMP-4, but not BMP-6, increase the number of adrenergic cells which develop in quail trunk neural crest cultures. Exp Neurol 140:84-94.

Walsh C, Cepko CL (1993) Clonal dispersion in proliferative layers of developing cerebral cortex. Nature 362:632-635.

Williams BP, Park JK, Alberta JA, Muhlebach SG, Hwang GY, Roberts TM, Stiles CD (1997) A PDGF-regulated immediate early gene response initiates neuronal differentiation in ventricular zone progenitor cells. Neuron 18:553-562.

Wilson PA, Hemmati-Brivanlou A (1995) Induction of epidermis and inhibition of neural fate by BMP-4. Nature 376:331-333.

Winnier G, Blessing M, Labosky PA, Hogan BL (1995) Bone morphogenetic protein- 4 is required for mesoderm formation and patterning in the mouse. Genes Dev 9:2105-2116.

Wozney JM (1989) Bone morphogenetic proteins. Prog Growth Factor Res 1:267-280.

Wozney JM, Rosen V, Celeste AJ, Mitsock LM, Whitters MT, Kriz RW (1988) Novel regulators of bone formation: molecular clones and activities. Science 242:1528-1534.

Wozney JM, Rosen V, Byrne M, Celeste AJ, Moustsatsos I, Wang EA (1990) Growth factors influencing bone development. J Cell Sci Suppl 109:833-844.

Xuan S, Baptista CA, Balas G, Tao W, Soares VC, Lai E (1995) Winged helix transcription factor BF-1 is essential for the development of the cerebra hemispheres. Neuron 14:1141-1152.

Yan XX, Zheng DS, Garey LJ (1992) Prenatal development of GABAimmunoreactive neurons in the human striate cortex. Dev Brain Res 65:191-204.

Yoshikawa H, Rettig WJ, Takaoka K, Alderman E, Rup B, Rosen V, Wozney JM, Lane JM, Huvos AG, Garin-Chesa P (1994a) Expression of bone morphogenetic proteins in human osteosarcoma. Cancer 73:85-91.

Yoshikawa H, Rettig WJ, Lane JM, Takaoka K, Alderman E, Rup B, Rosen V, Healey JH, Huvos AG, Garin-Chesa P (1994b) Immunohistochemical detection of bone morphogenetic proteins in bone and soft-tissue sarcomas. Cancer 74:842-847. 